\title{
Impact of Different Nitrogen Amount and Seeding Rates on Growth and Yield of NERICA 4 Rice Varieties in Upland Conditions
}

\author{
Bayissa Gedefa $^{1^{*}}$ Hisashi Urayama ${ }^{2}$ Yoshie Yageta ${ }^{2}$ \\ 1.Bako Agricultural Research Center, P.O.Box, 03, Bako, Ethiopia \\ 2.JICA Tsukuba International Center 3-6 Koyadai, Tsukuba-shi, Ibaraki-ken, Japan
}

\begin{abstract}
With the recent breakthrough in the development of the New Rice for Africa (NERICA) for the upland production system and the high demand for rice, farmers' interest in growing upland rice has increased. A field experiment was conducted at Tsukuba International center, Japan from May to October 2019 to evaluate the response of rice to seed rate and nitrogen fertilizer application and also determine economically optimum seed rate and nitrogen level for NERICA-4 upland variety. The experiment contained factorial combination of four levels of nitrogen $\left(0,30,60,90 \mathrm{~kg} \mathrm{ha}^{-1}\right.$ and two seed rates $\left(60 \& 80 \mathrm{Kg} \mathrm{ha}^{-1}\right)$. The experiment was laid out in randomized complete block design plot arrangement with three replications. The results from this study indicated that seed rate showed no significant effect on total dry matter weight, plant length, SPAD value, Leaf area index, panicle number, spikelet number, ripening ratio and grain yield while the total number of tillers was significant. However, nitrogen fertilizer rates significantly $(\mathrm{p}<0.05)$ affected in plant length, tiller number, SPAD value, dry matter and Leaf area index. Except 1000grain, all the yield and yield component parameters have also shown a significant increase up to the rate of $90 \mathrm{~kg} \mathrm{~N}$ ha- 1 . The highest grain yield (3340 $\mathrm{kg} \cdot \mathrm{ha}-1)$ was recorded using $90 \mathrm{~kg} \mathrm{~N} \mathrm{ha}^{-1}$ followed by $60 \mathrm{~kg} \mathrm{~N} \mathrm{ha}^{-1}\left(3200 \mathrm{~kg} \mathrm{ha}^{-1)}\right.$ and the lowest yield $\left(2100 \mathrm{~kg} \mathrm{ha}^{-1}\right)$ was recorded from control . Marginal rate of return analysis is also showed that the treatment with $\mathrm{N}$ fertilizer rate of $90 \mathrm{~kg} \mathrm{~N} \mathrm{ha}{ }^{-1}$ and seed rate $60 \mathrm{~kg} \mathrm{ha}^{-1}$ gave the highest Marginal rate of return $1217 \%$ followed by the treatment with $\mathrm{N}$ fertilizer rate of $60 \mathrm{~kg} \mathrm{~N}$ ha-1 and seed rate $60 \mathrm{~kg} \mathrm{ha}-1$.The general trend of the data indicated that the fertilizer rate has a greatest impact on grain yield compared to the seed rate of rice crop. Based on this study using 60 $\mathrm{kg} / \mathrm{ha}$ seed rate and application of $90 \mathrm{~kg} \mathrm{~N} \mathrm{ha}^{-1}$ gives high grain yield for rice crop production at experimental site.
\end{abstract}

Keywords: Economic profit, Seed rate, $\mathrm{N}$ fertilizer rate, Optimum grain yield, Marginal rate of return

DOI: $10.7176 / \mathrm{JNSR} / 12-4-05$

Publication date: February $28^{\text {th }} 2021$

\section{Introduction}

Rice is a stable food for more than half of the world population. It is not only a main source of calories but also an important source of income and employment (Zhao et al., 2011).With the recent breakthrough in the development of the New Rice for Africa (NERICA) for upland production system and the high demand for rice, farmers' interest in growing upland rice has increased .In Ethiopia, rice has become one of the most important crops whereby its production and area coverage increase every year (Tesfaye et al., 2005).

Despite its considerable importance, yield of the crop is very low especially in case of upland rice as farmers have limited access to production technologies. High yields are indeed possible under upland conditions. Under ideal conditions on experiment stations, yields of 7.0 and $7.2 \mathrm{t} / \mathrm{ha}$ have been reported in Philippines and Peru respectively (IRRI, 1986). It is also indicted that a quantity as high as 5.4t/ha was reported in Nigeria (Abifarin et al., 1972). Appropriate agronomic packages coupled with adequate nutrient supply at an appropriate time play are pivotal role in expression of yielding potential of crops. Among these, insufficient nitrogen fertilizers and inappropriate seed rats are important and research on these limiting factors will surely lead to high yields. Therefore, to increase the yield and yield components of the crop, it is necessary to apply Optimum seed rate and nitrogen rate which are economically feasible to the farmers.

Nitrogen is the most essential element that is applied most frequently and with high amount in rice production. High-yielding rice cultivars needs large amount of nitrogen to achieve acceptable grain yields. But application of nitrogen fertilizer either in excess or less than optimum rate affects both yield and quality of rice to remarkable extent (Shukla et al., 2015).

Seed rate is among the crucial factors that limit yield of rice and the most important agronomic aspect which need due attention. Profitability and productivity of rice can be improved through use of optimum seeding rate at economically and agronomic ally viable levels. When the plant density exceeds an optimum level competition among plants for light above ground and nutrients below ground becomes sever (Bloch et al, 2002). Consequently, plant growth slows down and the grain yield decreases. However, very low plant density may not enable to attain the yield plateau (Hay and Wolker, 1989). 
However, in Ethiopia and particularly with farmers in western Oromia region, there still remains an information gap with regard to knowledge on Optimum seed and nitrogen rate to be used in upland rice cultivation. Therefore, the objectives of this experiment are to determine appropriate seed rate and nitrogen level and evaluate the economics of various seed rate and nitrogen level for optimum grain yield of rice in upland condition.

\section{Material and Methods}

\section{Soil property of experimental site}

For soil analysis, before planting soil samples were randomly taken from the experimental site at a depth of $15 \mathrm{~cm}$ using an auger and the samples were mixed thoroughly to produce one representative composite sample. The soil samples were air-dried and ground to pass 2 and $0.5 \mathrm{~mm}$ (for total $\mathrm{N}$ ) sieves. Then it was analyzed at the soil laboratory for $\mathrm{pH}$, total carbon, nitrogen, available $\mathrm{P}$ and exchangeable $\mathrm{K}$ by following standard procedure. The soil chemical properties shown in table1, has slightly acidic nature with optimum total nitrogen content.

Table1. Analytical result of Soil properties of the experimental field

\begin{tabular}{lll}
\hline No & Properties & Values \\
\hline 1. & $\mathrm{pH}\left(\mathrm{H}_{2} \mathrm{O}\right)$ & 6.2 \\
2. & Total carbon $\left(\mathrm{g} \mathrm{kg}^{-1}\right)$ & 35.5 \\
3. & Total Nitrogen $\left(\mathrm{g} \mathrm{kg}^{-1}\right)$ & 3.22 \\
4. & Available P( Bray II, $\left.\mathrm{mg} \mathrm{kg}^{-1}\right)$ & 68.7 \\
5 & Exchangeable K $\left(\mathrm{cmolc} \mathrm{kg}^{-1}\right)$ & 2.09 \\
\hline
\end{tabular}

\section{Climatic conditions of experimental site}

Climatic data was collected throughout the growing season using digital meteorological instruments at Tsukuba International center weather station. Monthly rainfall in ( $\mathrm{mm})$, temperature in (deg.C) and solar radiation $(\mathrm{MJ} / \mathrm{m} 2)$ are presented in (Fig1.).

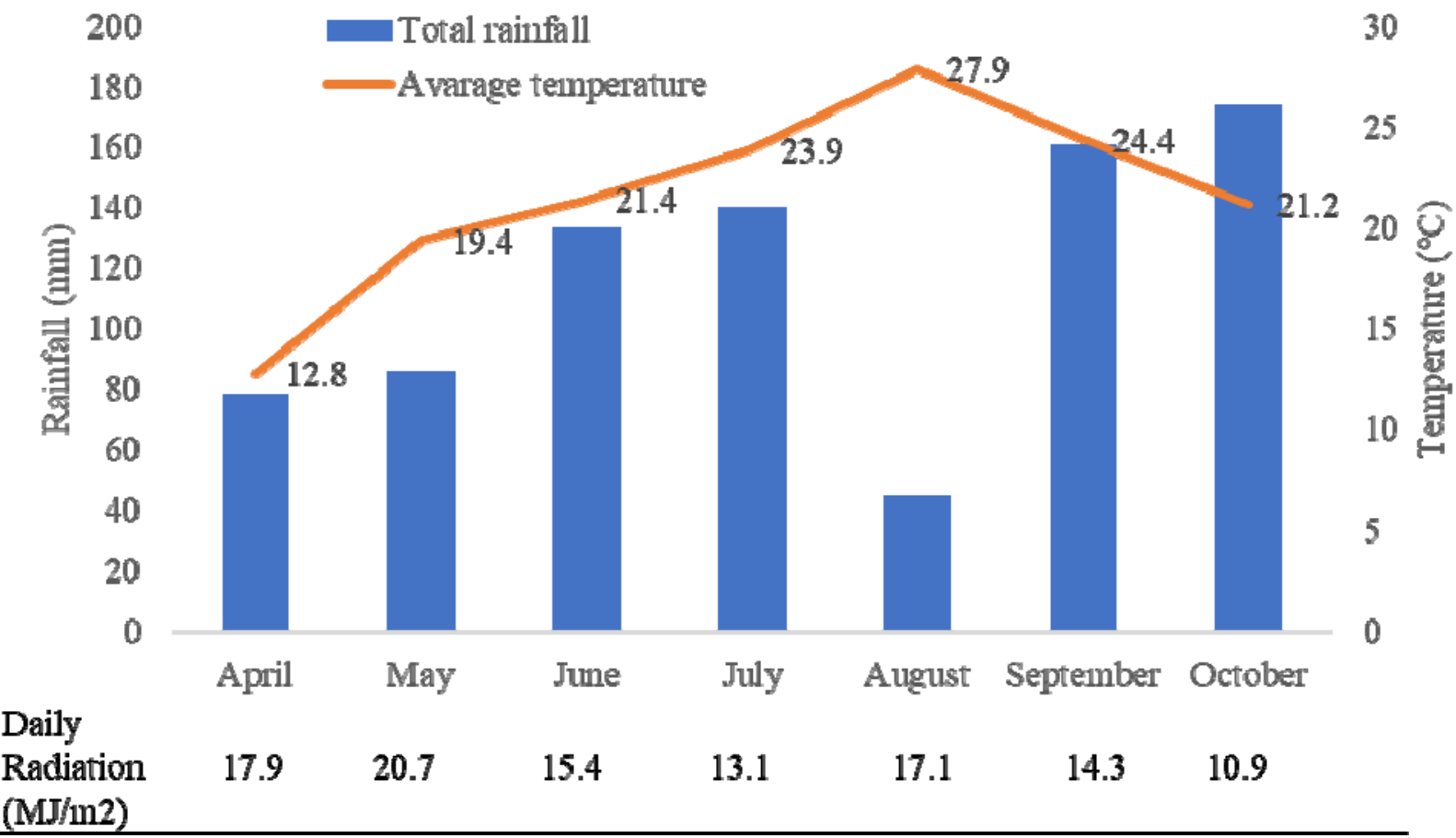

Fig.1. Temperature, precipitation and Solar Radiation of the experimental site

Treatments were comprised of two factors: namely two seed rate levels (60, and 80, $\left.\mathrm{kg} \mathrm{ha}^{-1}\right)$, and four levels of nitrogen $\left(0,30,60\right.$, and $\left.90 \mathrm{~kg} \mathrm{~N} \mathrm{ha}^{-1}\right)$. The experiment were arranged in a randomized completed block design with eight treatment and three replications. The plot size was $3 \mathrm{mx} 3 \mathrm{~m}$ and space between plots $0.5 \mathrm{~m}$ whereas $0.5 \mathrm{~m}$ space between blocks was left. The rice variety called NERICA4 (which have high yielding and medium maturity) was used. Seed were selected using salt solution of 1.06 specific gravity. 100 seeds of this variety were counted, soaked in water for 24 hours and then incubated at $30{ }^{\circ} \mathrm{C}$ for 72 hours to test the viability. To prevent fungal diseases the seed were disinfected with Tough block ( Talaromycles flavns powder hydrating agent )at 
the rate of 200 time solution and after short drying the seeds were coated with (Thiram) as bird repellent ( $1 \%$ of seed weight). Planting was done manually by drilling in to furrows of $2-3 \mathrm{~cm}$ depth the seeds at row spacing of $45 \mathrm{~cm} .2-3$ days after sowing Pre emergency herbicide pendemetheline (GO-GO-SAN) was applied for early weed control, second and third weeding were done manually 45 days after emergency.

Table2. Treatments combination

\begin{tabular}{lll}
\hline Seeding rate $\left(\mathbf{~ k g ~ h a}^{-1}\right)$ & $\begin{array}{c}\text { Factors } \\
\text { Nitrogen amount }\left(\mathbf{~} \mathbf{k g ~ h a}^{-\mathbf{1}}\right)\end{array}$ & Treatments combination \\
\hline $60(60 \mathrm{~S})$ & $0(\mathrm{~N} 0)$ & $\mathrm{S} 60 \mathrm{~N} 0$ \\
& $30(\mathrm{~N} 30)$ & $\mathrm{S} 60 \mathrm{~N} 30$ \\
& $60(\mathrm{~N} 60)$ & $\mathrm{S} 60 \mathrm{~N} 60$ \\
& $90(\mathrm{~N} 90)$ & $\mathrm{S} 60 \mathrm{~N} 90$ \\
$80(80 \mathrm{~S})$ & $0(\mathrm{~N} 0)$ & $\mathrm{S} 80 \mathrm{~N} 0$ \\
& $30(\mathrm{~N} 30)$ & $\mathrm{S} 80 \mathrm{~N} 30$ \\
& $60(\mathrm{~N} 60)$ & $\mathrm{S} 80 \mathrm{~N} 60$ \\
$90(\mathrm{~N} 90)$ & $\mathrm{S} 80 \mathrm{~N} 90$ \\
\hline
\end{tabular}

\section{Fertilizer application rate and timing}

For all the plots, 100 of $\mathrm{P} 2 \mathrm{O} 5$ and $80 \mathrm{~kg} \mathrm{ha}^{-1}$ of $\mathrm{K}_{2} \mathrm{O}$ were applied as $\mathrm{P}$ and $\mathrm{K}$ sources respectively. All phosphorous and $75 \%$ of the potassium were applied at basal whereas applied the rest of the potassium fertilizer was applied at 50 days before heading. Nitrogen was applied two times as basal and top dressing by using Ammonium Sulphate. As basal fertilizer (2/3 of total amount) and top dressing applies 50 days after sowing (DAS) $1 / 3$ of total amount.

Table 3.Application time and amount of chemical fertilizer

\begin{tabular}{llll}
\hline Nutrient & Basal kg ha $\left(\right.$ or gm $\left.^{-2}\right)$ & $\begin{array}{l}\text { Top dressing* } \\
\left(\mathrm{kg} \mathrm{ha}^{-1} \text { or gm }\right.\end{array}$ & Total $\left(\mathrm{kg} \mathrm{ha}^{-1}\right.$ or gm $\left.^{-2}\right)$ \\
\hline $\mathrm{N} 30$ & $10(57)$ & $30(171)$ \\
$\mathrm{N} 60$ & $20(114)$ & $20(114)$ & $60(342)$ \\
$\mathrm{N} 90$ & $40(228)$ & $30(171)$ & $90(513)$ \\
$\mathrm{P}_{2} \mathrm{O}_{5}$ & $60(342)$ & $0(0)$ & $100(686)$ \\
$\mathrm{K}_{2} \mathrm{O}$ & $100(686)$ & $20(79)$ & $80(197)$ \\
\hline
\end{tabular}

*Top dressing: 50DAS (days after sowing).

\section{Measurement of growth parameters}

Investigations of growth parameters were recorded five times during the growth period within time interval of fifteen days (15 days) apart. The first observation was carried out at early tilling stage, at active tillering, maximum tillering, and panicle initiation and at heading stages. Five sampling areas of $50 \mathrm{~cm}$ each were randomly selected in each plot from which growth parameters data were observed and were excluded in border sampling to avoid border effect. The growth parameters were investigated on plant height, tiller number, SPAD value, Leaf area index (LAI) at 35 Days After Sowing( DAS), 50 DAS, 65DAS, 80 DAS and dry matter weight at panicle initiation and at heading time.

\section{Yield and yield components}

An area of $1 \mathrm{~m}^{2}$ was used for partial harvesting to determine yield and yield components. Harvesting was done 30 days after heading (DAH) and number of panicles were counted and recorded. After drying the panicles for one week in green house bringing the moisture content to $14 \%$, threshing of grains had followed and \% of ripened grain was determined by separating filled grain from empty grains by using water of specific gravity 1.0. Then is followed determination of 1000 grain weight. Lastly spikelet number per panicle was also determined by calculating the total numbers of grains both filled and empty divide grains which were harvested per plot. All these yield components were used to calculate for the final yield per square meter which was subsequently converted to corresponding yield in kilogram per hectare.

\section{Data analysis}

The data collected on different parameters were statistically analyzed using Stat Cel 3 program. After analysis ANOVA the differences between the treatment means were compared by using the result of multiple comparisons method of Tukey Kramer test at significance (P5\% level of significance. To identify the economic optimum rate of nitrogen fertilizer and seeding rate, economic analysis was also done using the CIMMYT partial budget analysis methodology (CIMMYT, 1988). 


\section{Result and Discussion \\ Plant Length}

Data on plant length was collected at 35 days, 50Days, 65 days, 80days after sowing and heading time was recorded. Fig 2 showed plant length increased gradually in all treatments up to the final observation on heading time. The analysis of variance at $\mathrm{p}<0.05$ showed that there were significant difference among the four nitrogen amount applied at all sampling dates. The highest plant height was observed in the higher nitrogen level (N90 kg $\mathrm{ha}^{-1}$ and $\mathrm{N} 60 \mathrm{~kg} \mathrm{ha}^{-1}$ )) respectively. The lowest plant height was recorded from control treatment (zero nitrogen level) at all sampling dates. However, there were non-significant differences in plant height between seed rate ( $\mathrm{S} 60$ and $\mathrm{S} 80 \mathrm{~kg} \mathrm{ha}^{-1}$ ) at all growth stage .The general trend of the data indicated that the fertilizer rate has a greatest impact on plant length compared to the seed rate of rice crop. There was also no interaction effect observed between seed rate and nitrogen level .Two seed rate showed almost similar length plant of at 35 DAS, 50 DA 65DAS, 80DAS and heading time.

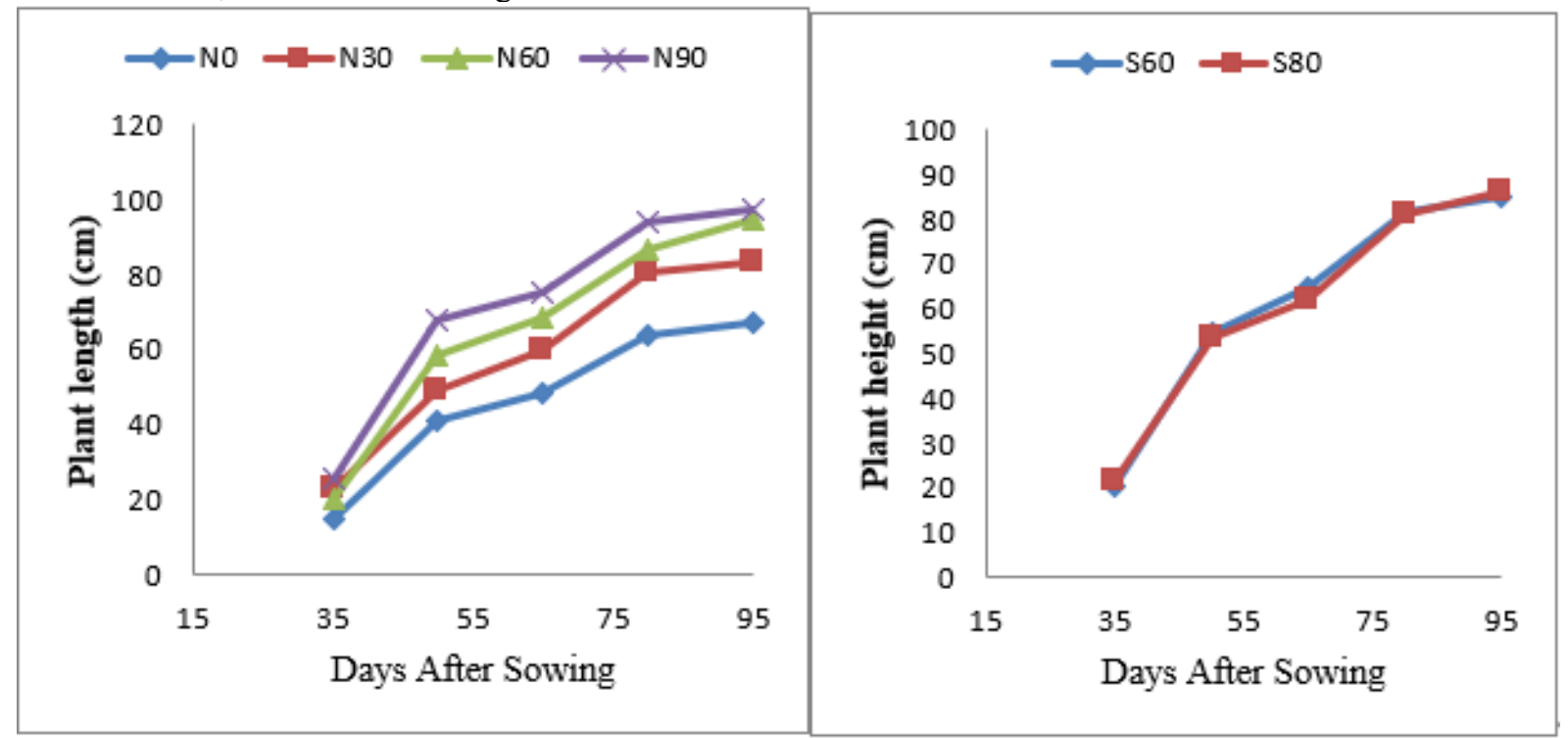

Fig.2. Effect of nitrogen level and Seed rate on plant length.

\section{Number of tiller}

Number of tillers per $\mathrm{m}^{2}$ of rice increased over time by gradual elevation of nitrogen fertilizer up to 80 days of after planting afterwards showed a falling trend. Data presented in Fig.3. Indicated that seed rate had significant $(\mathrm{P}<0.05)$ effect on tillers $\mathrm{m}^{-2}$. It is evident from the data that maximum tillers $\left(69.85 \mathrm{~m}^{-2}\right)$ were noted when plots were seeded with $80 \mathrm{~kg} \mathrm{ha}^{-1}$ (S80), while minimum tillers $\left(59.50 \mathrm{~m}^{-2}\right.$ ) were recorded when $60 \mathrm{~kg} \mathrm{ha}^{-1}$ seed rate was used (S60). The tillering potential was much higher at higher seed rate, when compared to lower seed rate. It might be due to that the number of tillers $\mathrm{m}^{2}{ }^{2}$ increased with increase in seeding rate,

The data further showed that different nitrogen levels had significantly $(\mathrm{P}<0.01)$ affected number of tillers $\mathrm{m}-2$. The highest number of tiller was recorded in the higher nitrogen level $\mathrm{N} 90\left(90 \mathrm{~kg} \mathrm{~N} \mathrm{ha}^{-1}\right)$ while the lowest number of tiller per $\mathrm{m}^{2}$ was recorded with no nitrogen fertilizer (N0). This might be due to increased nitrogen rate; therefore it is thought it could be led to greater stimulation of vegetative growth. All fertilizer levels significantly affected at vegetative and reproductive growth of the plant depending upon the availability of needed nutrition which leads to proportional increase in tillers $\mathrm{m}^{-2}$. These results are also in conformity with Ayoub et al., (1994), who reported that $120 \mathrm{~kg} \mathrm{~N} \mathrm{ha}^{-1}$ gave significantly the highest tillers $\mathrm{m}^{-2}$. However the interaction effect of the seed rate and amount of nitrogen was not significant. 


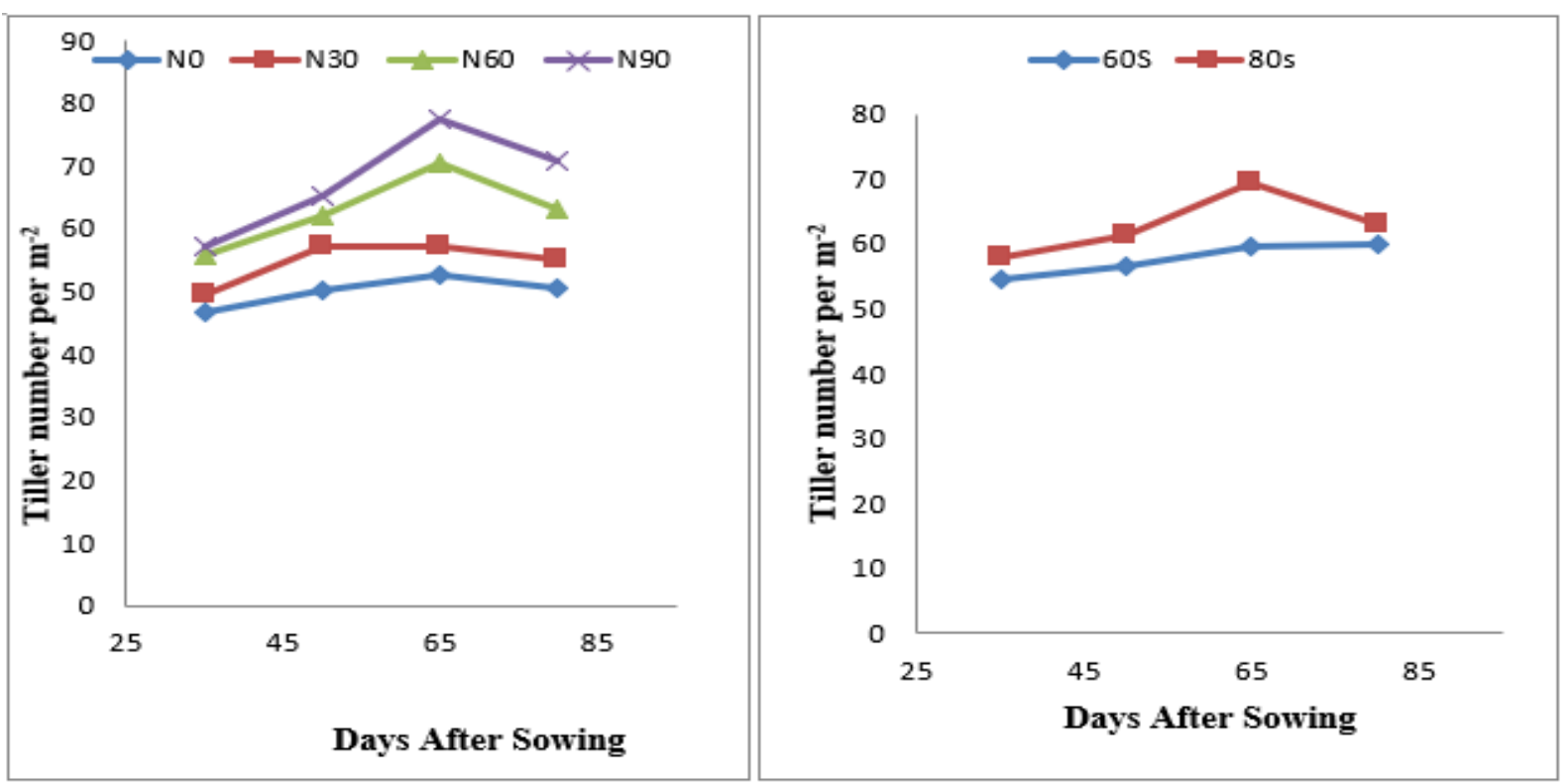

Fig.3. Effect of nitrogen level and Seed rate on tlller number.

\section{SPAD value}

SPAD value $\mathrm{m}^{-2}$ was significantly $(\mathrm{P}<0.01)$ affected by different nitrogen levels. It is clear from the data that maximum SPAD value (50.1 m-2) was recorded for plots treated with $90 \mathrm{~kg} \mathrm{~N}$ ha-1 (N90), followed by plots in which $60 \mathrm{~kg} \mathrm{~N}^{-1}$ (N60) was applied which was statistically similar to N30 (45.1 SPAD value m-2), while minimum (43.1) SPAD value $\mathrm{m}^{-2}$ were recorded from control plots (N0). Generally, SPAD value increased with growth of young leaves and chlorophyll formation at early growth stage. However, analysis of ANOVA data presented in (Fig4.) indicated that SPAD value $\mathrm{m}-2$ were not significantly $(\mathrm{P}<0.05)$ affected by different seed rate. The data also indicated that no interaction between seed rate and nitrogen levels at $(\mathrm{P}<0.05)$. SPAD value indicted chlorophyll content of NERICA 4 was as shown below.

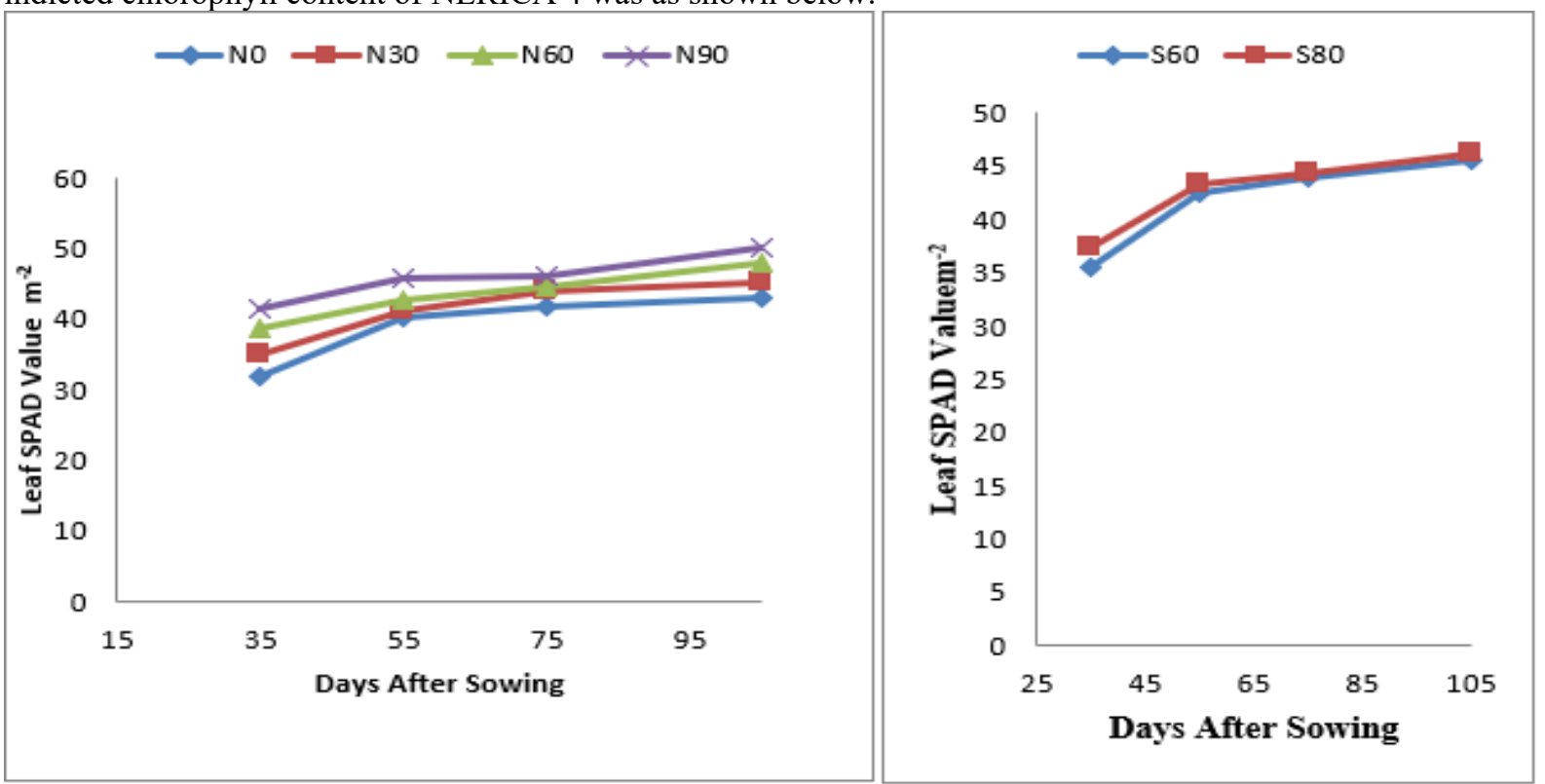

Fig.4. Effect of nitrogen level and Seed rate on Leaf SPAD Value.

\section{Leaf area index}

Leaf area index was investigated at panicle differentiation and heading stage. At both panicle differentiation stage and heading stage there were no significant difference on seed rate and interaction effect of seed rate and application of nitrogen level. However there was significant difference on different level of nitrogen application at $\mathrm{P}<0.05$ (Table4). Nitrogen fertilizer $\left(90 \mathrm{~kg} \mathrm{~N} \mathrm{ha}^{-1}\right)$ ) was gave the highest leaf area index. These may attributed with number of tiller in a given area. Similar trends were shown with nitrogen level $\left(90 \mathrm{~kg} \mathrm{~N} \mathrm{ha}^{-1}\right)$. 
Table4. Leaf Area Index at Panicle differentiation and heading stage

\section{Treatments}

\begin{tabular}{ll}
\hline Seed rate & S60 \\
& S80 \\
& Tukey(HSD)-5\% Significance \\
& Significance \\
Nitrogen__Level & N0 \\
& N30 \\
& N60 \\
& N90 \\
& Tukey (HSD) - (5\%) \\
S60 & N0 \\
& N30 \\
& N60 \\
& N90 \\
S0 & N30 \\
& N60 \\
& N90 \\
& Seed X Nitrogen \\
Interaction &
\end{tabular}

\section{Rice Growth stage}

Panicle initiation

$\begin{array}{cc}2.6 \mathrm{c} & 2.98 \mathrm{c} \\ 2.5 \mathrm{c} & 2.97 \mathrm{c} \\ \mathrm{ns} & \mathrm{ns} \\ & \\ 2.38 \mathrm{~b} & 2.77 \mathrm{~b} \\ 2.5 \mathrm{a} & 2.96 \mathrm{ab} \\ 2.65 \mathrm{a} & 3.06 \mathrm{ab} \\ 2.65 \mathrm{a} & 3.1 \mathrm{a} \\ * * & * \\ 2.36 \mathrm{c} & 2.7 \mathrm{ab} \\ 2.50 \mathrm{ab} & 3.00 \mathrm{ab} \\ 2.67 \mathrm{~b} & 3.10 \mathrm{~b} \\ 2.70 \mathrm{a} & 3.10 \mathrm{a} \\ 2.40 \mathrm{c} & 2.83 \mathrm{ab} \\ 2.50 \mathrm{c} & 2.93 \mathrm{ab} \\ 2.63 \mathrm{c} & 3.03 \mathrm{ab} \\ 2.60 \mathrm{c} & 3.1 \mathrm{ab} \\ \mathrm{ns} & \mathrm{ns} \\ 5.5 & 6.2\end{array}$

In each column, common letters indicates non-significant difference by Turkeys' Honestly Significant difference (HSD) at 5\% level; ns non-significant, * significant at the 0.05 level; ** significant at the 0.01 level

\section{Dry weight}

Dry weight production by rice plants increased progressively with the advancement of growth stages and reached rice peak at maturity (Table5).Dry weight was affected by the different level of nitrogen application at both panicle initiation stage and heading stage. $90 \mathrm{kgha}^{-1}$ of nitrogen level has produced significantly higher dry weight than control $\left(0 \mathrm{~kg} \mathrm{ha}^{-1}\right)$. However, dry weight was not significantly influenced by the seed rate at panicle and heading stage. Different seed rate application on (other hand) showed similar stem and leaf dry weight (table5). Interaction effect of the seed rate and nitrogen level was not significant.

Table5. Dry weight at Panicle differentiation and heading stage

\begin{tabular}{|c|c|c|c|}
\hline \multirow[t]{2}{*}{ Treatments } & & \multicolumn{2}{|c|}{ Rice growth stage } \\
\hline & & $\begin{array}{l}\text { total dry weight }\left(\mathrm{g} \mathrm{m}^{-2}\right) \\
\text { at Panicle initiation }\end{array}$ & $\begin{array}{l}\text { Dry weight }\left(\mathrm{gm}^{-2}\right) \text { at } \\
\text { Heading stage }\end{array}$ \\
\hline \multirow[t]{4}{*}{ Seed rate } & S60 & $133.09 \mathrm{~d}$ & $224.09 c$ \\
\hline & $\mathrm{S} 80$ & $135.86 \mathrm{~d}$ & $224.23 c$ \\
\hline & Tukey(HSD)-5\% & ns & ns \\
\hline & Significance & & \\
\hline \multirow[t]{5}{*}{ Nitrogen_Level } & No & $125.11 b$ & $215.28 \mathrm{ab}$ \\
\hline & N30 & $131.80 \mathrm{c}$ & $224.8 b$ \\
\hline & N60 & $136.28 \mathrm{a}$ & $227.45 b$ \\
\hline & N90 & $144.75 a$ & $229.13 a$ \\
\hline & Tukey (HSD) - (5\%) & $* *$ & $*$ \\
\hline \multirow[t]{4}{*}{ S60 } & No & $124.06 \mathrm{bc}$ & $216.06 \mathrm{c}$ \\
\hline & N30 & $131.03 \mathrm{c}$ & $223.7 b$ \\
\hline & N60 & $133.26 \mathrm{ab}$ & $229.93 a$ \\
\hline & N90 & $144.03 b$ & $226.7 b c$ \\
\hline \multirow[t]{4}{*}{ S80 } & No & 126.17 & $214.5 b c$ \\
\hline & N30 & $132.57 \mathrm{c}$ & $225.9 b c$ \\
\hline & N60 & $139.3 b$ & $224.967 b c$ \\
\hline & N90 & $145.45 a$ & $231.57 \mathrm{bc}$ \\
\hline Interaction & Seed X Nitrogen & ns & ns \\
\hline $\mathrm{CV}(\%)$ & & 6.05 & 2.9 \\
\hline
\end{tabular}

In each column, common letters indicates non-significant difference by Turkeys' Honestly Significant difference (HSD) at 5\% level; ns non-significant, * significant at the 0.05 level; ** significant at the 0.01 level 


\section{Yield and Yield components \\ Number of Panicle $\mathbf{m}^{-2}$}

Nitrogen levels had significant effect on the number of panicles per meter square of rice (Table 6). The number of panicle per $\mathrm{m}^{2}$ increased with increased level of nitrogen. The highest number of panicle per $\mathrm{m}^{2}(248.67)$ was recorded when $90 \mathrm{~N} \mathrm{~kg} \mathrm{ha}^{-1}$ was applied while the lowest (157.50) from $0 \mathrm{Nkg} \mathrm{ha}^{-1}$ (control treatment). The number of effective tillers rather than total number of tillers contributes more to enhance productivity of rice plant. The lower of tiller number in present study was attributed to the failure in competition for lower level of nitrogen and aggravated death of the tillers due to mutual shading. (Fageria,.. et al, 1997). Another explanation is that, competition for assimilates exists between developing panicles and young tillers during the beginning of panicle development causing suppression of growth of many young tillers. However number of panicles per $\mathrm{m}^{2}$ was not affected by seeding rate.

\section{Spikelet number Panicle ${ }^{-1}$}

Number of spikelet per panicle varied significantly due to different levels of applied nitrogen. Number of spikelet per panicle increased with the increase of nitrogen levels. The highest number of spikelet per panicle was recorded (86.89) at $90 \mathrm{~N} \mathrm{~kg} \mathrm{ha}^{-1}$ While, the lowest number of spikelet (71.20) per panicle of rice was observed at $0 \mathrm{~N} \mathrm{~kg} \mathrm{ha}^{-1}$. Application of nitrogen fertilizer improved grain number of rice. Higher number of grains per panicle at higher nitrogen rate could be due to higher nitrogen absorption which favored formation of higher number of branches per panicle. However, number of spikelet per $\mathrm{m}^{2}$ was not affected by seeding rate. The data also indicated that no interaction between seed rate and nitrogen levels at $(\mathrm{P}<0.05)$.

\section{0 grain Weight}

Amount of nitrogen levels and seed rate had no significant effect on the 1000 grain weight per meter square of rice (Table 6.). However, the maximum thousand grain weights were observed at $90 \mathrm{~N} \mathrm{~kg} \mathrm{ha}^{-1}(26.43 \mathrm{~g})$ which was statistically similar with $60 \mathrm{~N} \mathrm{~kg} \mathrm{ha}^{-1}$. The lowest thousand grain weights was produced with $0 \mathrm{~kg} \mathrm{~N}$ ha-1 $(23.7 \mathrm{~g})$ which was similar to that of 0 and $30 \mathrm{~N} \mathrm{~kg} \mathrm{ha}^{-1}$. In case of thousand grain weight, the variation is very low among the treatments as it known to be by the genetically controlled character. Similar results were found by other scientists (Maske, N.S., 1997) with nitrogen fertilizer management and concluded that there was little opportunity to improve grain size through agronomic management.

\section{Paddy Yield in kg ha ${ }^{-1}$}

Data indicated that significant difference of $(\mathrm{P}<0.05)$ grain yield was recorded only nitrogen fertilizer rate however, the seed rate and the interaction of nitrogen fertilizer and seed rate were not significant to alter grain yield (Table6). The highest grain yield $\left(3340 \mathrm{~kg} \mathrm{ha}^{-1}\right)$ was recorded using $90 \mathrm{~N} \mathrm{~kg}$ ha ${ }^{-1}$ followed by $60 \mathrm{~N} \mathrm{~kg}$ $\mathrm{ha}^{-1}\left(3200 \mathrm{~kg} \mathrm{ha}^{-1}\right)$ and the lowest yield $\left(2100 \mathrm{~kg} \mathrm{ha}^{-1}\right)$ was recorded from control (Table 6). Overall paddy yields obtained in this experiment were generally lower than the potential of the variety. A.E, Et al (2008) states the potential yields of NERICA4 was $5 \mathrm{t} /$ ha under upland conditions. This low yields obtained might have been caused by unfavorable weather conditions (drought and relatively high temperature, typhoon) experienced during booting, heading and ripening stage. Yoshida (1981) reported that unfavorable weather conditions during heading and ripening may hampered continued growth and development of unfilled spikelet. Grain yield of rice plant is highly relying on the number of spike-bearing tillers produced by each plant, filled grains and grains weigh (Huang,.et al 2011) .In this experiment, it is considered that at higher nitrogen level showed efficient of nitrogen for good assimilation for translocation and dry matter production of sink. 